\title{
The Social Skills of Students in the Pandemic Period (The Case Study in SMAN 1 Kedunggalar, Ngawi District, East Java, Indonesia)
}

\author{
Prima Retnaning Mareta ${ }^{1}$, Akhmad Arif $\mathbf{M}^{2}$, Susanto $^{3}$ \\ 1,2,3 Universitas Sebelas Maret, Surakarta, Indonesia \\ primaretnaning37@gmail.com,arif_mussadad_fkip@yahoo.co.id,susantofibuns@staff.uns.ac.id
}

\begin{abstract}
The increasingly prolonged pandemic period and its unclear ending have disrupted all human activities, one of which is learning activities in school. After the physical distancing policy is implemented, student-learning activities are carried out at home. This results in a decrease in the affective skills of students. Besides, the teachers also experience limitations in monitoring students' affective behavior. Hence, this study's goal is to determine the extent to which students' social skills during the pandemic period. The research subjects were students of Kedunggalar 1 Senior High School (SMA Negeri 1 Kedunggalar), Ngawi Regency, with 76 students as respondents who were randomly selected from various classes, majors, and gender. This research was a qualitative descriptive study. Data collection techniques used questionnaires. Data analysis in this study referred to an interactive analysis model consisting of the stages of data reduction, data presentation, and data verification. Based on the results of this research, it can be seen how the attitude of students' social skills is during the pandemic.
\end{abstract}

Keywords

social skills, students, pandemic

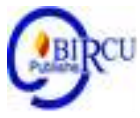

\section{Introduction}

Since December 2019, the world has been shocked by the news of the spread of the Covid-19 virus (Coronavirus disease 19) which has claimed many victims in Wuhan, China. As reported on the website of covid.cdc.gov, 85337 people were infected in Wuhan with 4634 people died and 80536 were recovered. In the beginning, the virus spread only in Wuhan, yet it has also started to spread to various countries, including Indonesia. Due to the rapid spread of the virus, many countries in the world are competing to fabricate the Covid-19 vaccine. The World Health Organization (WHO) has begun to make various studies on preventing the transmission of the Covid-19. The suggestions of physical distancing, wearing masks, washing hands, and avoiding crowds have become a campaign for the WHO and governments in various countries to suppress and reduce the infection of the Covid-19.

Those suggestions are to reduce and prevent the transmission of the virus, which has an impact on all sectors of human life. The world of education is one of the sectors affected by Covid-19 pandemic. Since last March, almost all formal-education in Indonesia, from kindergarten to university level, has been encouraged to study at home. The regulation of study at home arises various impacts on the learning process and the formation of affective and psychomotor skills of students. Since March 2020, at least 290.5 million students around the world have been disturbed due to closed schools (Mastura \& Santaria, 2020). 
No direct face-to-face study causes students to fully have virtual interaction with both teachers and their friends. Online learning is an alternative to learning during the Covid-19 pandemic. Both teachers and students are required to more utilize digital technology through online learning, in which digital technology allows teachers and students to be in different places during the learning process (Natalie, 2015). Online learning requires the internet network with accessibility, connectivity, flexibility, and the ability to generate various types of learning interactions (Moore et al., 2011). According to Yunus \& Rizki, (2020) the condition of the Covid-19 pandemic has also accelerated the revolution of Industry 4.0. This can reduce the social interactions of students. Besides, this also limits teachers to do observation and assessment of students' affective and psychomotor abilities. These conditions make the social skills of students undeveloped. As teachers and education personnel who are required to assess students' abilities as a whole, it is expected that they can overcome the existent problems. Teachers can make breakthroughs and innovations in developing the affective and psychomotor especially social skills of students.

Social skill is the ability to interact with other people in a social context in a specific way that is socially acceptable or valued and benefits others (Comb \& Slaby, 1977). Social skills are needed by students to live in the community. Widoyoko (2011) has argued that social skills are needed for life (life skills) in a multicultural society, a democratic society, and a global society that is full of competition and challenges. Social skills involve communication skills both orally and in writing, and the ability to work together with other people both in small groups and in large groups. Meanwhile, Golmen (2005) has divided social skills into 10 elements, including influence, communication, leadership, the catalyst for change, conflict management, network binding, collaboration and cooperation, and team skills.

Social skills are very valuable assets for students. With social skills, students can interact properly in their community; maintain student acceptance and positive relationships as social beings where they are. Students can obtain social skills through a socialization process with the surrounding environment. The socialization process is a process when children learn the values and behaviors received from society (Hildayani et al., 2011).

The development of the children's social skills is not easy and formed suddenly so that efforts are needed to provide space for children to get used to, practice, and improve social skills through learning. However, these can be achieved when the conditions are normal. Unfortunately, at this time, the Covid-19 pandemic outbreak is still ongoing which limits the students' social interaction and the students' social space. Nevertheless, although they cannot physically meet face-to-face, they can still interact socially through social media. However, the question is how the social skills of students during the pandemic are, when the social space is very limited with no physical contact and only through the virtual world.

Many studies have examined the learning process during the pandemic and social skills. Giatman et al (2020) in the Nonformal Education Journal of UNNES have reported an article with the title of e"Online Learning Quality Control in the Pandemic Covid-19 Era in Indonesia". This research examined data related to learning from Padang State University and exhibited that about half of students are still not ready for online learning due to inadequate facilities and infrastructure such as gadgets and internet signals. Furthermore, Robandi (2020) has published a report of learning policies during the pandemic in the E-Tech Journal entitled "An Analysis of Education Policy in the Pandemic Covid-19". The research referred to the circular letter issued by the Ministry of Education and Culture No. 4 of 2020 regarding learning policies during the pandemic. The results of this study explained that the constraints in online learning during the pandemic for both teachers and students.

Based on the research of Hardika et al (2020) published in the Journal of Nonformal Education with the title of "Literacy about Covid-19: Trending Words, News Sources, Compression, and Community Curiosity in Perspectives Nonformal Education", there was a perception of non-formal education interrelated to learning during the pandemic. This research 
observed other things from a different side regarding the conditions of the Covid-19 pandemic. From the perspective of non-formal education, the researcher investigated new terms that often appeared in the mass media. The research was conducted in the city of Malang with a population of 158 samples selected by purposive sample. The results revealed that there were additional new vocabularies correlated to the Covid-19 and there were various sources of understanding and curiosity about news and vocabularies related to new vocabularies. Of all the researches regarding the covid-19 pandemic, evaluation of online learning during the pandemic is important, such as the study of Siswati et al (2020) in the Nonformal Education Journal with the title of "Evaluation of Online-Based Student Learning: Models During New Normal Pandemic Covid19 in Indonesia". The study took a population of students in Padang who were randomly selected by 153 respondents and exhibited that online learning was very helpful in the Covid-19 pandemic conditions even though around half of the respondents said that it was not yet effective. The expectation of students during the new normal period of learning is that they can meet face to face even with the health protocols.

Mushfi (2017) in the Pedagogic journal of Nurul Jadid Probolingo University, has observed social interaction models in elaborating social skills. Maryani \& Syamsudin (2009) observed the study of the development of social studies learning programs to improve social skills competence. Dewanti et al (2016) have investigated the relationship between social skills and the use of smartphone gadgets on the students' achievement of SMA Negeri 9 Malang, published in Jurnal Kajian Bimbingan dan Konseling (Journal of Guidance and Counseling Study). Sugiarti \& Santoso (2013) have also reported the difference of the application of the cooperative learning model with numbered head together (NHT) type and jigsaw on the increasing social skills in high school students (the case study in Karangturi Senior High School, Semarang/ SMA Karangturi Semarang), published in Wacana journal.

Those various studies have become the references for this study to carry out. However, those studies were performed under normal conditions. In contrast, the pandemic condition causes online learning and students' active social interaction was greatly reduced. Therefore, this study is conducted to acknowledge the impact of the pandemic, which not only requires students to study online but also have social skills.

\section{Research Methods}

This research was a descriptive qualitative study. The research subjects were students of Kedunggalar 1 Senior High School (SMA Negeri 1 Kedunggalar). The respondents were 76 students who were randomly selected (random sampling). Random Sampling is a sampling technique from the population members carried out randomly without paying attention to the strata in the population (Sugiyono, 2001). The data collection technique was in the form of an open questionnaire with a Likert scale. The Likert scale is a scale used to measure the attitudes, opinions, and perceptions of a person or group of people regarding the social phenomenon (Sugiyono, 2017). The respondents filled out the questionnaire provided via google form with 7 questions. The results of the questionnaire were then compiled, analyzed, and concluded in each question item according to the indicator.

\section{Discussion}

To prevent the transmission of covid-19, the Indonesian Ministry of Education and Culture recommends all schools to conduct online learning. Similarly, Zhang et al (2004) stated that the use of the internet and multimedia technology can change the way of conveying knowledge and can be an alternative to learning held in traditional classrooms. Corona Archives world such as coronarchiv from the University of Hamburg Germany has 
recommended examples of schools with a new culture during the pandemic, that is with tight seating and health protocols (Grammes, 2020). Although these rules have been implemented, we cannot guarantee that these rules will be obeyed by all educational institutions formally. This can make a very difficult and impact on the education system in Indonesia. Especially those affected are students and teachers. Teachers are required to continue delivering material using some media while students are expected to follow the material presented through the online media platform. The drastic changes in learning models create a culture shock for students and teachers. The first obstacle the limited mastery of technology and information because not all teachers in Indonesia understand the use of technology, which teachers born before the 1980s will experience technology failure due to their unfamiliarity with the technology used today (Martorejo, 2020). On the other hand, when the teachers already have online learning competencies, not all students have the infrastructure supporting online learning such as smartphones, computers, and internet networks, as reported by Regianti's research (2020). However, the most affected by these changes are the students. Quoting from Aji (2020), online learning has affected students' psychology and skills. Besides the limitations of online learning facilities and infrastructure, because of the online learning culture, students suddenly become technology-savvy students, especially in schools in the countryside (Purwanto et al., 2020). The process of building student skills is hampered because social interaction can only be done through social media without any physical contact. Meanwhile, social skills are needed by students to get along in society. Even though there is online learning during this pandemic period, are students still able to develop their social skills? Seeing there are no social interaction activities as in school. This becomes interesting to explore and discuss. The following Table 1 is the review data related to the skills of students during the Covid-19 pandemic.

Table 1. The results of the student questionnaire regarding online learning responses $\&$ social skills in social media

\begin{tabular}{|c|c|c|c|c|c|}
\hline \multirow{2}{*}{ No } & \multirow{2}{*}{ Statement } & \multicolumn{4}{|c|}{ Result of Opinion (\%) } \\
\hline & & SS & $\mathbf{S} \quad \mathbf{B}$ & $\mathbf{S d} / \mathbf{J}$ & SJ/SS \\
\hline 1 & Impressions of Online Learning & 3.9 & $22.4 \quad 36.8$ & 23.7 & 13.2 \\
\hline 2 & Use of Social Media Groups & 26.3 & $\begin{array}{ll}43.4 & 11.8 \\
\end{array}$ & 13.2 & 5.3 \\
\hline 3 & Expressing Opinions in social media forums / groups & 1.3 & 34.2 & 31.6 & 7.9 \\
\hline 4 & Praising Others & 7.9 & $32.9 \quad 28.9$ & 27.6 & 2.6 \\
\hline 5 & Offering Helps & 5.3 & 42.131 .6 & 18.4 & 2.6 \\
\hline 6 & Advising Friends / Other People & 11.8 & $22.4 \quad 31.6$ & 32.9 & 1.3 \\
\hline \multirow{2}{*}{ No } & \multirow{2}{*}{ Statement } & \multicolumn{4}{|c|}{ Result of Opinion (\%) } \\
\hline & & $\mathbf{S}$ & $\mathbf{P}$ & $\mathbf{T P}$ & \\
\hline 7 & Fight with Friends / Other People & 9.2 & $47.4 \quad 25$ & 8.4 & \\
\hline
\end{tabular}

Information:

SS : Very Happy / Very Often/ Very frequent

S : Happy / Often

B : Normal

J : : Rarely/ Seldom

$\mathrm{Sd} \quad: \mathrm{Sad}$

SS : Very Sad

SJ : Very rarely

$\mathrm{P}$ : Ever

TP : Never 


\subsection{Online Learning}

Table 1 shows that the majority of students or 28 respondents $(36.8 \%)$ from 76 students feel normal with online learning situations. Besides, 17 respondents $(22.4 \%)$ are happy while 3 respondents (3.9\%) feel very happy with online learning. Further, 18 respondents $(23.7 \%)$ are sad while 10 respondents $(13.2 \%)$ are very sad about online learning.

This online learning situation creates various responses from students. Student responses can also be influenced by environmental conditions and supporting facilities for online learning. This study result is in line with the findings of the research by Bobby Briando who observed students' perceptions of online learning during the pandemic at Tanjungpinang 4 Senior High School (SMAN 4 Tanjungpinang). The study revealed that the majority of students, from the total respondents of 180 students, as many as $92(50.1 \%)$ gave 'normal' answers regarding online learning during the pandemic. The normal and neutral responses are both midpoints in the questionnaire addressed by the respondents (students). Thus, it can be concluded that the students have normal or neutral responses regarding online learning during the Covid-19 pandemic. Nevertheless, it is different from the research of Firman \& Rahman (2020) who studied the Biology Education Study Program, Faculty of Teacher Training and Education, University of West Sulawesi, showing that the majority of students are quite satisfied with online learning because they have the flexibility of space and time even though they have some technical problems, but students still happy with online learning.

\subsection{Use of Social Media Groups}

The conditions of the Covid-19 pandemic are not an obstacle for students to interact socially with peers because they are still facilitated by communication technology. Moreover, social media is very accommodating for social interaction activities. According to Prabowo \& Nurmaliah, (2013) one indicator of social skills is communication skills. Meanwhile, the communication skills have 5 indicators: 1 ) the ability to listen with empathy; 2) the ability to convey ideas with empathy; 3) communication skills with technology; 4) the ability to convince others; 5) courage to express opinions.

Table 1 presents data about the use of groups on social media to find out communication skills. Based on Table 1, the majority of students or 33 respondents $(43.4 \%)$ often use groups on social media while 20 students (26.3\%) are very frequent. Meanwhile, 10 students $(13.2 \%)$ are rarely using social media groups while 4 students $(5.3 \%)$ are very rare. Furthermore, only 9 students $(11.8 \%)$ answered 'normal'. Hence, from 76 respondents, the majority of students still have the ability of social skills with the indicator of the ability to communicate with technology.

\subsection{Expressing Opinions in Social Media Forums / Groups}

Having the courage to express opinions is included in communication skills which is one of the social skills indicators (Prabowo \& Nurmaliah, 2013). The Covid-19 pandemic has not prevented the meeting or discussion forums because communication technology in the form of social media has been very accommodating for exchanging messages via text messages, sounds, pictures, videos, even video calls.

To what extent students have the courage to express their opinions in forums on social media, can be seen from the data in Table 1. According to Table 1, the majority of students or 26 students $(34.2 \%)$ feel normal to express opinions during the pandemic. Meanwhile, 19 students $(25 \%)$ are often and 1 student $(1.3 \%)$ is very frequent in expressing opinions on social media groups. Further, as many 24 students $(31.6 \%)$ rarely express opinions while 6 students $(7.9 \%)$ are very rarely expressing. From these data, it can be concluded that the ability to communicate in the field of courage to express an opinion is classified as moderate. 


\subsection{Praising Others}

Caldarella and Merrell in Gimpel \& Merrell (1998) have declared that there are 5 (five) dimensions in social skills. First is peer relations, which is shown through positive behavior towards peers such as praising or advising others, offering help to others, and playing with others. Second is self-management, which reflects adolescents with good emotions, able to control emotions, following existing rules and boundaries, and able to accept criticism well. The third is academic ability, which is exhibited through fulfilling assignments independently, completing individual assignments, and carrying out teacher directions well. The fourth is compliance, which demonstrates adolescents who can follow rules and expectations, use their time well, and share something. Finally, the fifth is assertive behavior (Assertion), which is dominated by the abilities that make a teenager can display the right behavior in the expected situation.

Referring to this opinion, praising behavior is included in the peer relation category or good relations with peers, which is one indicator of social skills. With the existence of social media developing nowadays, communication among peers is very easy. We can even find out the various activities of friends from their social media and sometimes we find good and interesting things so that we can get praise from others. To investigate how students 'peer relations ability from praising others' behavior, it can be seen in Table 1.

Of 76 respondents, 15 respondents $(32.9 \%)$ often praise others while 6 respondents (7.9\%) think very often. This behavior is a positive thing. Meanwhile, 22 respondents (28.9\%) act normal. Additionally, 21 respondents (27.6\%) rarely praise others while 2 respondents $(2.6 \%)$ do it very rarely. From the presentation of these data, it can be concluded that the ability of students to build good relationships (peer relations) from the behavior of praising others is very good.

\subsection{Offering Helps}

Still in the peer relation indicator, one of the social skills is building good relationships with peers by offering helps to friends. According to Gimpel and Merrell, how the ability of the students' social skills can be seen from good relationships with peers in the behavior of offering help to others. In this study, this indicator can be found by the data in Table 1.

Of 76 respondents or students, 32 respondents $(42.1 \%)$ have been often offering help to their peers while 4 respondents $(5.3 \%)$ do it very often. Then 14 respondents $(18.4 \%)$ rarely offer help to other people while 2 respondents $(2.6 \%)$ said very rarely offering assistance. For the rest, only 24 respondents $(31.6 \%)$ feel normal in offering helps during the pandemic. Therefore, based on these results, the students' peer relation behavior is quite good so that it can be said that they have quite good social skills.

\subsection{Fight with Others}

According to Gimpel and Merrell (1998), fighting with others is contrary to indicators of student social skills. Fighting with other people is the opposite of peer relations and selfmanagement, which are indicators of social skills. Table 1 presents data to understand to what extent students have good peer relations and self-management skills, which means having a small possibility of fighting with other people.

Of the total 76 respondents, 36 respondents $(47.4 \%)$ have ever fought with their friends while 7 respondents $(9.2 \%)$ fight very often. Meanwhile, 14 respondents $(18.4 \%)$ have never fought with friends. The remaining 19 respondents (25\%) rarely fight with their friends. Hence, based on these data, the ability of peer relations and self-management is quite good because the tendency to fight with friends is quite small, although the majority say they have, it does not happen often. 


\section{Conclusion}

The existence of the Covid-19 pandemic causes the class learning to be transferred to online learning, and the presence of the physical distancing policy has reduced the students' direct social interaction with their peers. However, the formation of social skills can still run because social interactions can still be established through social media applications. Therefore, there is no reason for students not to learn and not to improve social skills to provide them with life in society.

\section{References}

Bobby, B. (2020). Persepsi Siswa Terhadap Pembelajaran Online di Masa Pandemi pada Sekolah Menengah Atas Negeri Empat Tanjungpinang. Proceeding in Webinar \& Call Papers, Universitas Negeri Malang

Comb \& Slaby. (1977). Social Skills Training With Children. New York: Plenum Press

Dewanti, T. C., Widada, \& Triyono. (2016). Hubungan Antara Keterampilan Sosial dan Penggunaan Gadget Smartphone Terhadap Prestasi Belajar Siswa SMA Negeri 9 Malang. Jurnal Kajian Bimbingan dan Konseling, 1(3), 126-131. http://dx.doi.org/10.17977/um001v1i32016p126

Firman \& Rahman, S. R. (2020). Pembelajaran Online di Tengah Pandemi Covid-19, Indonesian Journal of Educational Science (IJES), 2(2), 81-89. DOI: 10.31605/ijes.v2i2.659

Giatman, M., Siswati, S., \& Basri, I. Y. (2020). Online Learning Quality Control in the Pandemic Covid-19 Era in Indonesia, Jurnal Nonformal Education, 6(2), 168-175. DOI: https://doi.org/10.15294/jne.v6i2.25594

Gimpel, G. A., \& Merrel, K. W. (1998). Social Skills of Children and Adolescents: Conceptualization, Assessment, Treatment. Mahwah, NJ: Erlbaum

Goleman, D. (2005). Working with Emotional Inteligence (Kecerdasan Emosi untuk Mencapai Puncak Prestasi). Jakarta: PT Gramedia Pustaka Utama

Grammes, T. (2020). COVID-19 Pandemic, Emergency Remote Teaching and Social Science Education, Journal of Social Science Education, 19 (SI), 1-7. DOI 10.4119/jsse-3544

Aji, R. H. S. (2020). Dampak Covid 19 pada Pendidikn di Indonesia: Sekolah, Keterampilan, dan Proses Pembelajaran, SALAM: Jurnal Sosial \& Budaya Syar'I, 7(5), 395-402. DOI: https://doi.org/10.15408/sjsbs.v7i5.15314 Abstract - 0 PDF - 0

Hardika, Aisyah, E. N., \& Kurniawan, T. (2020). Literacy about Covid-19: Trending Words, News Sources, Comprehension, and Community Curiosity in Perspectives Nonformal Education, Journal Nonformal Education, 6(2) 161-167. DOI: https://doi.org/10.15294/jne.v6i2.24898

Hildayani, R., Sugianto, M., Tarigan, R., Handayani, E., Pudjiati, R., \& Mary, A. (2013). Psikologi Perkembangan Anak. Jakarta: Universitas Terbuka

Moore, J. L., Deane, C. D., \& Galyen, K. (2011). e-Learning, online learning, and distance learning environments: Are they the same?, The Internet and Hinger Education, 14 (2) 129-135. https://doi.org/10.1016/j.iheduc.2010.10.001

Maryani, E., \& Syamsudin, H. (2009). Pengembanagan Program Pembelajaran IPS untuk Meningkatkan Kompetensi Ketrampilan Sosial, Jurnal Penelitian, 9(1) 1-15

Martorejo, T. N. (2020). Pandemi Covid-19: Ancaman atau Tantangan bagi Sektor Pendidikan, Jurnal Binus, 7(1), 1-15.

Mastura \& Santaria, R. (2020). Dampak Pandemi Covid-19 Terhadap Proses Pengajaran Bagi Guru dan Siswa, Jurnal Studi Guru dan Pembelajaran, 3(2) 289-295 
Merrell, K. W. (2003). Behavioral, social, and emotional assessment of children and adolescents. New Jersey: Lawrence Erlbaum Associates

Natalie, M. B. (2015). Distance Education, International Encyclopedia of the Social \& Behavioral Sciences: Second Edition, 2, 567-570.

Mishara, L., Gupta, T., \& Shree, A. (2020). Online teaching-learning in higher education during lockdown period of COVID-19 pandemic, International Journal of Educational Research Open, 1, 10012. https://doi.org/10.1016/j.ijedro.2020.100012

Mushfi, M. (2017) Model Interaksi Sosial dalam Mengelaborasi Keterampilan Sosial, Jurnal Pedagogik, 4(2), 211-227.

Prabowo, Listyo, S., \& Faridah, N. (2013). Perencanaan Pembelajaran pada Bidang Studi Tematik, Muatan Lokal, Kecakapan Hidup, Bimbingan dan Konseling. Malang: UIN Maliki Press

Purwanto, A., Pramono, R., Asbari, M., Hyun, C. C., Wijayanti, L. M., Putri, R. S., \& Santoso, P. B. (2020). Studi Ekplorasi Dampak Pandemi Covid-19 Terhadap Proses Pembelajaran Online di Sekolah Dasar, EduPsyCouns: Journal of Education, Psychology and Counseling, 2(1), 2716-4446

Regianti, H. A. (2020). Kendala Pembelajaran Daring Guru Sekolah Dasar di Banjarnegara, Jurnal Pendidikan dan Pembelajaran ke-SD-an, 7(2), 297-302. DOI: https://doi.org/10.31316/esjurnal.v7i2.768

Robandi, D. (2020). An Analysis of Education Policy in the Pandemic Covid-19, Jurnal Ilmiah Teknologi Pendidikan, 8(2), 1-4. DOI : https://doi.org/10.24036/et.v8i1.109065

Siswati, S., Astiena, A. K., \& Savtri, Y. (2020). Evaluation of Online-Based Student Learning: Models During New Normal Pandemic Covid-19 in Indonesia, Journal Nonformal Education, 6(2), 148-155. DOI: https://doi.org/10.15294/jne.v6i2.25599

Sugiarti, R., \& Pribadi., S. A. (2013). Penerapan Model Pembelajaran Kooperatif Tipe Numbered Head Together (NHT) dan Jigsaw Terhadap Peningkatan Keterampilan Sosial pada Siswa SMA (Studi Kasus di SMA Karangturi Semarang), Jurnal Wacana, 5(2), 1-15. DOI: https://doi.org/10.13057/wacana.v5i2.10

Sugiyono (2001) Metode Penelitian. Bandung: Alfabeta (2017) Metode Penelitian Kuantitatif, Kualitatif dan R\&D. Bandung: Alfabeta

Widoyoko, E. P. (2011). Evaluasi Program Pembelajaran Panduan Praktis bagi Pendidik dan Calon Pendidik. Yogyakarta: Pustaka Pelajar

Yunus, N. R., \& Rezki, A. (2020). Kebijakan Pember $\neg$ lakuan Lock Down Sebagai Antisipasi Penye $\neg$ baran Corona Virus Covid-19. Salam: Jurnal Sosial Dan Budaya Syar-i, 7(3), 227-238.

Zhang, D., Zhao, J. L., Zhou, L., \& Nunamaker, J. F. (2004). Can e-learning replace classroom learning?, Communications of the ACM, 47(5), 75-79. 